\title{
THE EFFECT OF DEFICIT IRRIGATION APPLIED IN DIFFERENT PHENOLOGICAL PERIODS ON SAFFLOWER YIELD AND QUALITY
}

\author{
KARAŞ, E. \\ Osmangazi University, Department of Biosystem Engineering, Eskisehir, Turkey \\ (e-mail: ekaras@ogu.edu.tr) \\ (Received $15^{\text {th }}$ Oct 2019; accepted $23^{\text {rd }}$ Jan 2020)
}

\begin{abstract}
A field study was carried out to investigate the effect of deficit irrigation applied in the different phenological periods of safflowers (Carthamus tinctorius L.) at the Central Anatolian region in Turkey between 2007 and 2009. A randomized split block design in fourteen subjects with three replications was used. According to the results, the highest yield was obtained from the issue when there was no water stress during the growing period. It was found that there was a decrease in yield from the subjects when periodic water deficit was applied at various rates. At the end of the research, the most effective periods for yield were determined as flowering, vegetation, and yield formation. The average seasonal water consumption was between 234 and $591 \mathrm{~mm}$; the highest and the lowest grain yield was $5.10 \mathrm{t} \mathrm{ha}^{-1}$ and $2.48 \mathrm{t} \mathrm{ha}^{-1}$, respectively. Irrigation water usage efficiency (IWUE) ranged between $7.3 \mathrm{~kg} \mathrm{ha}^{-1} \mathrm{~mm}^{-1}$ and $11 \mathrm{~kg} \mathrm{ha}^{-1} \mathrm{~mm}^{-1}$. The amount of irrigation water applied had no effect on oil ratios ranging from $28.89 \%$ to $30.66 \%$. The effect of irrigation water applied was observed only on stearic and linoleic fatty acids. The coefficient of determination $\left(\mathrm{r}^{2}\right)$ of water-yield relationships during the experiment was obtained as 0.44 , 0.71 , and 0.68 , respectively.
\end{abstract}

Keywords: water use efficiency, evapotranspiration, water-yield relationship, fatty acids, oil content

\section{Introduction}

The effects of global warming, which has increased markedly since 1980, are much more noticeable in arid and semi-arid climates (Pankova and Konyushkova, 2014; Cook et al., 2014). Due to the increasing temperatures, drought in agricultural areas makes the management of soil water in agricultural lands more and more important (Diogo, 2018; Shkolnik et al., 2019). Drought forecasts suggest that it will be more effective in the Mediterranean basin, including the Central Anatolia region (Hertig and Tramblay, 2017; Lionello et al., 2017). The main effects of drought on agricultural areas are the decrease in rainfall, the increase in recurring periods of aridity, and the lowering of groundwater due to excessive irrigation and low penetration (Gouveia et al., 2017; Caloiero et al., 2018).

Management of soil moisture in the root area is vital for plants, determination of critical and water-sensitive periods and possible drought scenarios (Pan et al., 2018; Grecksch, 2019). The main objective of water management is to maximize yield by determining the periods during which the plant is most susceptible to water shortages and the levels of sensitivity during these periods. Thanks to the development of water management strategies in plant breeding, the main objective of productive agricultural management on a watershed basis are to irrigate more land with existing water and improve the efficiency of water use (Bacelar et al., 2013; Choudhury and Singh, 2016). The development of water-saving deficit irrigation programs is also a way of ensuring food safety (Ward and Pulido-Velazquez, 2008; Shammout et al., 2018).

In Turkey, production of oilseeds (sunflower, cotton, soybean, rapeseed and safflower seeds) ranges from 2.3 to 2.7 million tonnes annually. Oilseed production distribution in 
Turkey consists of sunflower (46\%), cottonseed (41\%), soybean (6\%), canola (5\%), and safflower $2 \%$ (TUIK, 2018). Although safflower is a widely recommended plant in arid conditions such as exists in Central Anatolia, some preliminary studies have shown that the plant will produce very positive results from irrigable conditions. Many studies have been carried out on plant water consumption, water use efficiency, yield, and quality under limited irrigation conditions of the safflower in Turkey (İstanbulluoğlu, 2009; İstanbulluoğlu et al., 2009; Öztürk et al., 2009). However, the research on growing safflower in arid and semi-arid conditions as in Central Anatolia has not been sufficient. This study aims to investigate the yield, some physical characteristics (grain weight, fat ratio) and changes in the fatty acid composition at various irrigation levels during the phenological periods of safflower plants in an arid and semi-arid climate.

\section{Material And Method}

\section{Site Description}

The experimental area is located at the Soil and Water Resources Research Institute in the Alpu plain, east of Eskişehir province in Central Anatolia, Turkey. The trial site coordinates are $39^{\circ} 46^{\prime}$ north latitude and $30^{\circ} 36^{\prime}$ east longitude, and the elevation is $780 \mathrm{~m}$ above sea level.

\section{Climate}

The climate characteristics of the research area are continental and fall under the influence of the Central Western Anatolia climate. In general, summers are hot and dry, and winters are cold and snowy. The average annual temperature is $10.7^{\circ} \mathrm{C}$, the first frost is on average October 18, the last frost is on average April 20, the lowest temperature is $-26.7^{\circ} \mathrm{C}$, the average annual rainfall is $343.2 \mathrm{~mm}$, the evaporation value is $975.7 \mathrm{~mm}$ and the annual average relative humidity is 62\% (SWRI, 2011). The monthly average temperature, rainfall and relative humidity values of the years when the trial period was carried out are given in Table 1.

Table 1. Some climatic values of the experimental area during the study

\begin{tabular}{c|cccc|ccccc|cccc}
\hline \multirow{2}{*}{ Month } & \multicolumn{4}{|c|}{ Temperature, ${ }^{\mathbf{0}} \mathbf{C}$} & \multicolumn{4}{c|}{ Rainfall, mm } & \multicolumn{3}{c}{ Relative Humidity, \% } \\
\cline { 2 - 13 } & $\mathbf{2 0 0 7}$ & $\mathbf{2 0 0 8}$ & $\mathbf{2 0 0 9}$ & Mean & $\mathbf{2 0 0 7}$ & $\mathbf{2 0 0 8}$ & $\mathbf{2 0 0 9}$ & Mean* & $\mathbf{2 0 0 7}$ & $\mathbf{2 0 0 8}$ & $\mathbf{2 0 0 9}$ & Mean* \\
\hline I & 0.0 & -3.5 & 0.9 & -0.2 & 42.2 & 13.1 & 66.3 & 36.1 & 74.1 & 72.2 & 71.2 & 74.8 \\
II & 1.5 & 0.0 & 3.1 & 1.3 & 14.2 & 2.7 & 74 & 26.7 & 68.1 & 59.4 & 66.6 & 70.3 \\
III & 5.4 & 8.4 & 4.6 & 5.0 & 24.0 & 29.9 & 39.8 & 35.6 & 63.0 & 56.1 & 60.5 & 63.5 \\
IV & 7.5 & 11.5 & 10.0 & 10.1 & 25.0 & 38.1 & 26.0 & 42.4 & 54.7 & 61.6 & 55.7 & 59.8 \\
V & 17.8 & 14.3 & 14.8 & 14.8 & 65.6 & 14.4 & 28.9 & 42.7 & 49.1 & 49.5 & 50.7 & 57.9 \\
VI & 20.8 & 20.2 & 20.4 & 18.6 & 58.6 & 2.8 & 7.9 & 31.2 & 47.9 & 40.9 & 41.0 & 54.6 \\
VII & 23.8 & 21.9 & 22.2 & 21.4 & - & 0.8 & 11.4 & 10.5 & 40.0 & 40.2 & 42.9 & 51.1 \\
VIII & 23.9 & 23.4 & 21.0 & 21.0 & 1.9 & 4.7 & 2.0 & 9.1 & 43.5 & 40.9 & 42.2 & 53.0 \\
IX & 17.7 & 17.0 & 16.5 & 16.9 & - & 30.9 & 7.2 & 13.4 & 44.9 & 54.7 & 52.8 & 54.8 \\
X & 12.6 & 11.7 & 14.5 & 11.7 & 19.1 & 8.1 & 18.3 & 25.6 & 57.7 & 59.0 & 52.1 & 61.1 \\
XI & 4.9 & 6.8 & 6.0 & 6.0 & 91.7 & 50.5 & 29.3 & 27.6 & 73.9 & 65.5 & 68.0 & 68.5 \\
XII & 0.6 & 1.5 & 4.6 & 2.1 & 46.1 & 34.7 & 69.7 & 42.3 & 73.3 & 68.5 & 69.7 & 75.7 \\
\hline Mean/Total & 11.4 & 11.1 & 11.6 & 10.7 & 388.4 & 230.7 & 380.8 & 343.2 & 56.0 & 54.2 & 56.1 & 62.1 \\
\hline
\end{tabular}

*Mean (1957-2011) 


\section{Soil}

Soil analysis tests, including physical (structure, volume weight) and chemical ( $\mathrm{pH}$, total salt, lime, phosphorus, potassium, organic matter) as well as infiltration tests were performed on the soils taken up to a depth of $120 \mathrm{~cm}$ at the research area (Tüzüner, 1990). The soil of the test area has a clay structure, consisting of slightly alkaline alluvial soils with $\mathrm{pH}$ values ranging between 7.50 and 8.03 , and salt values varying between $0.102 \%$ and $0.187 \%$. Although heavily structured, it is generally classified as too calcic. The soil of the test sites is defined as having high phosphorus, sufficient potassium, and low organic matter.

\section{Irrigation water quality}

The $\mathrm{pH}$ value of the irrigation water samples taken from the deep well in the research area was 6.8 , the EC value was 0.747 , the SAR value was 1.10 , and no boron problem was detected (Boyacı and Karas, 2011).

\section{Safflower variety}

The safflower plant variety, Dincer, which was used in the experiment, was registered in 1977 by the Eskişehir Anatolian Agricultural Research Institute. Plant height is around 90-110 cm, the flower color is orange, the grain color is white and the plant has a thorny structure. The plant usually lasts from 127-130 days in the growing season (Boyac1 and Karas, 2011).

\section{Experimental design and field work}

The experiment was conducted with a randomized split block design with 14 subjects and 3 replications (see Table 2). Irrigation subjects were arranged considering three different phenological periods (vegetative [V], flowering [F], yield formation [Y]) during the growing period. The plot areas were mouldboard ploughed in the fall and cultivated twice in the spring.

Table 2. Trial subjects

\begin{tabular}{c|c|c|c|c}
\hline \multirow{2}{*}{ Subjects } & \multirow{2}{*}{ Application } & \multicolumn{3}{|c}{ Stage of development } \\
\cline { 3 - 5 } & & Vegetative (V) & $\begin{array}{c}\text { Flowering } \\
(\mathbf{F})\end{array}$ & Yield formation (Y) \\
\hline $\mathrm{S}_{1}$ & $\mathrm{VFY}$ & $\mathrm{I}$ & $\mathrm{I}$ & $\mathrm{I}$ \\
$\mathrm{S}_{2}$ & $\mathrm{VFY}_{0}$ & $\mathrm{I}$ & $\mathrm{I}$ & 0 \\
$\mathrm{~S}_{3}$ & $\mathrm{VF}_{0} \mathrm{Y}$ & $\mathrm{I}$ & $\mathrm{I}$ & $\mathrm{I}$ \\
$\mathrm{S}_{4}$ & $\mathrm{~V}_{0} \mathrm{FY}$ & 0 & 0 & $\mathrm{I}$ \\
$\mathrm{S}_{5}$ & $\mathrm{VF}_{0} \mathrm{Y}_{0}$ & $\mathrm{I}$ & $\mathrm{I}$ & 0 \\
$\mathrm{~S}_{6}$ & $\mathrm{~V}_{0} \mathrm{FY}_{0}$ & 0 & 0 & 0 \\
$\mathrm{~S}_{7}$ & $\mathrm{~V}_{0} \mathrm{~F}_{0} \mathrm{Y}$ & 0 & $\mathrm{I}$ & $\mathrm{I}$ \\
$\mathrm{S}_{8}$ & $\mathrm{~V}_{60} \mathrm{FY}$ & $\mathrm{I}_{1}$ & $\mathrm{I}$ & $\mathrm{I}$ \\
$\mathrm{S}_{9}$ & $\mathrm{~V}_{40} \mathrm{FY}$ & $\mathrm{I}_{2}$ & $\mathrm{I}$ & $\mathrm{I}$ \\
$\mathrm{S}_{10}$ & $\mathrm{VF}_{60} \mathrm{Y}$ & $\mathrm{I}$ & $\mathrm{I}$ & $\mathrm{I}$ \\
$\mathrm{S}_{11}$ & $\mathrm{VF}_{40} \mathrm{Y}$ & $\mathrm{I}$ & $\mathrm{I}_{2}$ & $\mathrm{I}_{1}$ \\
$\mathrm{~S}_{12}$ & $\mathrm{VFY}_{60}$ & $\mathrm{I}$ & $\mathrm{I}$ & $\mathrm{I}_{2}$ \\
$\mathrm{~S}_{13}$ & $\mathrm{VFY}_{40}$ & $\mathrm{I}$ & $\mathrm{I}$ & 0 \\
$\mathrm{~S}_{14}$ & $\mathrm{~V}_{0} \mathrm{~F}_{0} \mathrm{Y}_{0}$ & 0 & 0 & $\mathrm{I}_{0}$ \\
\hline
\end{tabular}

Description of symbols: $\mathrm{S}_{1}$-Full irrigated, $\mathrm{I}_{1}-0.6 \times \mathrm{S}_{1}, \mathrm{I}_{2}-0.40 \times \mathrm{S}_{1}, 0$ - No irrigation 
In the research, no water stress occurred in the subjects of irrigation (VFY) during the growing period of the plant. On the other hand, there was a certain amount of water stress in all other subjects and at least one period. For example, in $\mathrm{VFY}_{0}$, no water stress occurred during vegetative and flowering periods and irrigation water was applied to meet plant water consumption needs during these periods; however, no irrigation was applied during the yield formation period. The index value in any period indicates the rate of application of irrigation water in that period. For example, the application of $\mathrm{V}_{60} \mathrm{FY}$, which is given as the subject of $S_{8}$ in Table 2 , shows that $60 \%$ of plant water consumption is given in the vegetative period and full irrigation is performed during flowering and yield formation periods.

The plots were arranged in October $\left(4.5 \mathrm{~m} \times 6.0 \mathrm{~m}=27 \mathrm{~m}^{2}\right)$, planted at the beginning of April and harvested $\left(3.9 \mathrm{~m} \times 5.0 \mathrm{~m}=19.5 \mathrm{~m}^{2}\right)$ at the beginning of September. In the experiment, safflower was planted in $30 \mathrm{~cm}$ plant-row spacing and $10 \mathrm{~cm}$ plant-on-plant row. Fertilization was carried out according to soil analysis results. Base fertilization was applied to the soil by mixing before planting. All the phosphorus fertilizer and half of the nitrogen fertilizer were given up to planting depth of 4-6 cm with planting. During the second fertilization period, the remaining nitrogen was applied under the soil. The fertilizer requirement of the plant was realized according to the research results proposed by Y1ldirım (2005); all parcels were based on $16 \mathrm{~kg} \mathrm{~N}, 8 \mathrm{~kg} \mathrm{P}_{2} \mathrm{O}_{5}$ as a pure substance. 20-20-0 compound fertilizer with planting, Ammonium nitrate (33\%) fertilizer was used as the top fertilizer.

\section{Irrigation treatments, water use, and soil moisture measurements}

In the experiment, the $\mathrm{V}, \mathrm{F}$ and $\mathrm{Y}$ phenological periods were selected for the determination of irrigation periods in the experiment. Also taken into consideration were the principles specified by Doorenbos and Kassam (1979). Irrigation applications were carried out considering the effective root depth of $90 \mathrm{~cm}$. Irrigation water was given to test plots utilizing a furrow method with plastic pipes and measured with a water meter. Soil moisture measurements were taken weekly from 0-30, 30-60 and 60-90 cm depths and determined by the gravimetric method.

Water budget equality was used to calculate plant water consumption.

$$
\mathrm{ET}_{\mathrm{a}}=\mathrm{I}+\mathrm{P}-\mathrm{R}-\mathrm{DP}+\mathrm{CR} \pm \Delta \mathrm{SF} \pm \Delta \mathrm{SW}
$$

where ETa: Actual evapotranspiration $(\mathrm{mm})$, I: irrigation water $(\mathrm{mm})$, P: precipitation $(\mathrm{mm}), \mathrm{R}$ : surface runoff $(\mathrm{mm}), \mathrm{DP}$ : deep percolation $(\mathrm{mm}), \mathrm{CR}$ : capillary rise, $\Delta \mathrm{SF}$ : subsurface flow $(\mathrm{mm}), \Delta \mathrm{SW}$ : change in soil water content $(\mathrm{mm})$.

In the experiment, rainfall and irrigation water are directly measured values. Since the amount of water given at the effective root depth is as much as the field capacity, it is assumed that there is no deep percolation.

The agricultural operations and observations including irrigation made during the trial years are given in Table 3.

\section{Seed Oil Content}

The seeds were dried in the oven for 4 hours at $40^{\circ} \mathrm{C}$ and then ground using a blender. 4 grams of dried safflower seeds were extracted with petroleum ether for 6 hours in a Soxhlet system according to the AOCS method (AOCS, 1993). The n-hexane and oil mixture obtained after extraction was filtered and separated under vacuum using a rotary 
evaporator (Heidolph ${ }^{\circledR}$ brand Laborota 4000 Efficient) at $45^{\circ} \mathrm{C}$. The crude oil ratio was calculated by weighing the obtained safflower oil weight.

Table 3. Agricultural operations and observations in the experimental years

\begin{tabular}{c|l|l|l}
\hline Agricultural applications and observations & $\mathbf{2 0 0 7}$ & $\mathbf{2 0 0 8}$ & $\mathbf{2 0 0 9}$ \\
\hline Fallow & $10 / 15$ & $10 / 10$ & $17 / 10$ \\
Tillage & $04 / 08$ & $03 / 28$ & $04 / 02$ \\
Seeding & $04 / 12$ & $04 / 02$ & $04 / 02$ \\
Germination & $04 / 28$ & $04 / 11$ & $04 / 24$ \\
Emergence & $05 / 02$ & $04 / 20$ & $04 / 30$ \\
Rosette & $05 / 20$ & $05 / 05$ & $05 / 30$ \\
Fertilizing & $05 / 30$ & $06 / 02$ & $05 / 25$ \\
First irrigation & $06 / 12$ & $06 / 05$ & $06 / 10$ \\
Flowering (\%5) & $06 / 28$ & $06 / 27$ & $06 / 28$ \\
Second irrigation & $07 / 04$ & $07 / 02$ & $07 / 02$ \\
Flowering (\%100) & $07 / 18$ & $07 / 06$ & $07 / 16$ \\
The beginning of maturidy period & $07 / 26$ & $07 / 25$ & $07 / 26$ \\
Third irrigation & $07 / 28$ & $08 / 01$ & $08 / 01$ \\
Harvest & $09 / 01$ & $08 / 28$ & $08 / 28$ \\
\hline
\end{tabular}

\section{Fatty Acid Composition}

The fatty acid composition of the safflower oils was analyzed by gas chromatography according to the AOCS standard method. The oil samples were diluted with hexane and converted into methyl esters by esterification. Fatty acid methyl esters were analyzed by Agilent 7890A model gas chromatography using a Supelco 2380 capillary column $(60 \mathrm{~m}$ x $0.25 \mathrm{~mm} \times 0.20 \mu \mathrm{m}$ ) and flame ionization detector (FID). Helium was used as carrier gas at a flow rate of $20 \mathrm{~cm} \mathrm{~s}^{-1}$. Injection, furnace and detector temperatures are 250, 185 and $260^{\circ} \mathrm{C}$, respectively. $1 \mu \mathrm{L}$ of methyl ester sample was injected into the device with a split ratio of $1 / 100$. Fatty acid methyl esters were determined by comparing retention times with reference standards. The amounts of fatty acid methyl esters were determined by using internal standard (Methyl nonadecanoate). The contents of palmitic (16:0), stearic (18:0), oleic (18:1), and linoleic (18:2) acids were determined using a computing integrator. The effects of the independent variables on oil content and palmitic, stearic, oleic, and linoleic acid concentrations of the oil were analyzed on a percentage basis.

\section{Statistical Analysis}

Statistical analysis of the data obtained from the research was carried out following the procedure proposed by Yurtsever (1984). All data were subjected to ANOVA based on general linear models for factorial arrangement of treatments in a completely randomised design using the Statview statistical package (SAS Institute, 1998). Multiple comparisons with Duncan were used to determine the effects of treatment.

\section{Water Use Efficiency}

Water Use Efficiency (WUE) is defined as the amount of carbon assimilated as biomass or grain (Yield, $\mathrm{Y} \mathrm{kg} \mathrm{ha}^{-1}$ ) produced per unit $(\mathrm{ET}, \mathrm{mm})$ of water used by the crop $\left(\mathrm{kg} \mathrm{ha}^{-1} \mathrm{~mm}^{-1}\right)$.

$$
W U E=\frac{Y}{E T}
$$


Irrigation Water Use Efficiency (IWUE): It takes into account the amount of irrigation water (IW, mm) applied during the trial period $\left(\mathrm{kg} \mathrm{ha}^{-1} \mathrm{~mm}^{-1}\right)$.

$$
I W U E=\frac{Y}{I W}
$$

\section{Water use-yield relationship}

The data obtained from the study were used linear regression to obtain the relationship between seasonal ET and yield. Seasonal yield response factor (ky) for each year was determined using the Stewart model (Stewart et al., 1977).

$$
\left(1-\frac{Y a}{Y m}\right)=k y\left(1-\frac{E T a}{E T m}\right)
$$

where, Ya, actual yield $\left(\mathrm{kg} \mathrm{ha}{ }^{-1}\right)$; Ym, maximum yield $\left(\mathrm{kg} \mathrm{ha}^{-1}\right)$; ETa, actual evapotranspiration $(\mathrm{mm})$, ETm, maximum evapotranspiration $(\mathrm{mm})$; ky, yield response factor

The ETa and ETm values in the Stewart equation are the actual ET and maximum ET values during the study. The ETa / ETm value in the equation is considered to be 1.00 for the absence of plant water stress; It is calculated by comparing the ETa value measured for other subjects where water stress occurs to the ETa value measured for the subject without water stress. The meaning of the Ky value can be interpreted as follows considering the results obtained:

$\mathrm{Ky}>1$ : crop response is very sensitive to water deficit with proportional larger yield reductions when water use is reduced because of stress.

$\mathrm{Ky}<1$ : crop is more tolerant to water deficit, and recovers partially from stress, exhibiting less than proportional reductions in yield with reduced water use.

$\mathrm{Ky}=1$ : yield reduction is directly proportional to reduced water use.

\section{Results and Discussion}

\section{The effect of water stress on grain yield}

The statistical results obtained during the study are given in Table 4, Table 5 and Figure 1. Seed yield ranged between 2.48 and $5.10 \mathrm{t}$ ha. The highest yield was obtained from full irrigation $\left(S_{1}\right)$ application and the lowest yield was obtained from the non-irrigation $\left(\mathrm{S}_{14}\right)$ subject. Seed yield showed significant fluctuations between years according to water applications. In the second and third years of the experiment, higher yields were recorded in the parcels where full water was applied, whereas no significant differences were observed between the years in $S_{10}$ application. In other applications, different reactions have occurred. This has led to significant interactions of the year $\mathrm{x}$ application. The combined analysis of the results have shown that seed yield was higher in the second year of the experiment compared to the other experimental years. While the highest seed yield was obtained from full irrigation application, the lowest yield was obtained from the rainfed conditions in the experiment. In general, decreasing irrigation water causes a reduction in seed yield. In the experiment, the flowering period was the most sensitive to yield loss, followed by the vegetation and yield-formation periods, respectively. The graph of the yield in the experiment carried out is given in Figure 1-A. 
Table 4. The effect of irrigation treatment on trial subjects

\begin{tabular}{|c|c|c|c|c|c|c|c|c|c|c|}
\hline \multirow[b]{2}{*}{ Subjects } & \multirow[b]{2}{*}{ Treatmen } & \multirow{2}{*}{$\begin{array}{c}\text { Yield } \\
\left(\mathrm{t} \mathrm{ha}^{-1}\right)\end{array}$} & \multirow{2}{*}{\begin{tabular}{|c|}
1000 Seed \\
weight \\
$(\mathrm{g})$
\end{tabular}} & \multirow{2}{*}{$\begin{array}{c}\text { IWUE } \\
\mathrm{kg} \mathrm{ha}^{-1} \mathrm{~mm}^{-1}\end{array}$} & \multirow{2}{*}{$\begin{array}{c}\text { Oil } \\
\text { rate } \\
(\%)\end{array}$} & \multicolumn{5}{|c|}{ Fatty Acid } \\
\hline & & & & & & $\begin{array}{c}\text { Myristic } \\
(\%)\end{array}$ & $\begin{array}{c}\text { Palmitic } \\
(\%)\end{array}$ & $\begin{array}{c}\text { cStearic } \\
(\%)\end{array}$ & $\begin{array}{c}\text { Oleic } \\
(\%)\end{array}$ & $\begin{array}{c}\text { Linoleic } \\
(\%)\end{array}$ \\
\hline $\mathrm{S}_{1}$ & VFY & $5.10^{\mathrm{a}}$ & $48.96^{\mathrm{a}}$ & $8.8^{c}$ & 27.83 & 0.11 & 6.17 & $2.14^{\mathrm{abc}}$ & 11.67 & $75.52^{a}$ \\
\hline $\mathrm{S}_{2}$ & $\mathrm{VFY}_{0}$ & $4.14^{b}$ & $47.67^{b c}$ & $9.1^{\mathrm{c}}$ & 28.85 & 0.12 & 6.07 & $2.04 \mathrm{bc}$ & 11.53 & $71.62^{c}$ \\
\hline $\mathrm{S}_{3}$ & $\mathrm{VF}_{0} \mathrm{Y}$ & $3.56^{\text {ef }}$ & $47.64^{b c}$ & $8.1^{\mathrm{d}}$ & 27.88 & 0.11 & 6.11 & $2.10^{b c}$ & 11.41 & $73.32^{b}$ \\
\hline $\mathrm{S}_{4}$ & $\mathrm{~V}_{0} \mathrm{FY}$ & $3.84^{\mathrm{cd}}$ & $48.58^{a b}$ & $8.0^{\mathrm{d}}$ & 28.77 & 0.13 & 6.37 & $2.10^{b c}$ & 11.85 & $71.97^{\mathrm{c}}$ \\
\hline $\mathrm{S}_{5}$ & $\mathrm{VF}_{0} \mathrm{Y}_{0}$ & $3.24^{\mathrm{g}}$ & $48.22^{\mathrm{abc}}$ & $10.2^{\mathrm{ab}}$ & 28.95 & 0.12 & 6.24 & $2.15^{\mathrm{abc}}$ & 11.32 & $71.49^{c}$ \\
\hline $\mathrm{S}_{6}$ & $\mathrm{~V}_{0} \mathrm{FY}_{0}$ & 3.56 ef & $48.58^{a b}$ & $9.9^{b}$ & 28.01 & 0.13 & 6.30 & $2.05^{b c}$ & 11.35 & $73.28^{b}$ \\
\hline $\mathrm{S}_{7}$ & $\mathrm{~V}_{0} \mathrm{~F}_{0} \mathrm{Y}$ & 3.52 ef & $48.62^{\mathrm{ab}}$ & $10.6^{\mathrm{a}}$ & 28.34 & 0.12 & 6.13 & $2.05^{b c}$ & 11.04 & $73.84^{b}$ \\
\hline $\mathrm{S}_{8}$ & $\mathrm{~V}_{60} \mathrm{FY}$ & $4.25^{b}$ & $47.96^{\mathrm{abc}}$ & $8.0^{\mathrm{d}}$ & 28.55 & 0.12 & 6.03 & $2.22^{\mathrm{ab}}$ & 11.37 & $73.77^{b}$ \\
\hline $\mathrm{S}_{9}$ & $\mathrm{~V}_{40} \mathrm{FY}$ & $4.04^{b c d}$ & $48.18^{a b c}$ & $7.9^{\mathrm{d}}$ & 28.46 & 0.12 & 6.09 & $2.10^{b c}$ & 11.48 & $73.98^{b}$ \\
\hline $\mathrm{S}_{10}$ & $\mathrm{VF}_{60} \mathrm{Y}$ & $4.13^{b}$ & $47.41^{\mathrm{cd}}$ & $7.7^{\mathrm{d}}$ & 28.55 & 0.11 & 6.03 & $2.06^{\mathrm{bc}}$ & 11.53 & $73.14^{b}$ \\
\hline $\mathrm{S}_{11}$ & $\mathrm{VF}_{40} \mathrm{Y}$ & $3.78 \mathrm{de}$ & $48.39^{a b c}$ & $7.9^{\mathrm{d}}$ & 28.08 & 0.11 & 6.02 & $2.06^{\mathrm{bc}}$ & 11.63 & $73.37^{b}$ \\
\hline $\mathrm{S}_{12}$ & $\mathrm{VFY}_{60}$ & $4.07 \mathrm{bc}$ & $46.59^{d}$ & $7.8^{d}$ & 28.12 & 0.12 & 6.13 & $2.05^{b c}$ & 11.43 & $73.97^{b}$ \\
\hline $\mathrm{S}_{13}$ & $\mathrm{VFY}_{40}$ & $3.85^{\mathrm{cd}}$ & $48.09^{a b c}$ & $7.8^{d}$ & 27.60 & 0.13 & 5.59 & $1.94^{\mathrm{c}}$ & 11.46 & $69.32^{\mathrm{d}}$ \\
\hline $\mathrm{S}_{14}$ & $\mathrm{~V}_{0} \mathrm{~F}_{0} \mathrm{Y}_{0}$ & $2.48^{\mathrm{h}}$ & $48.26^{\mathrm{abc}}$ & $10.8^{a}$ & 28.57 & 0.12 & 6.42 & $2.34^{\mathrm{a}}$ & 11.82 & $71.28^{\mathrm{c}}$ \\
\hline \multicolumn{2}{|c|}{ Mean } & 3.82 & 48.08 & 88 & 28.3 & 0.12 & 6.12 & 2.10 & 11.49 & 72.85 \\
\hline \multicolumn{11}{|c|}{ Year } \\
\hline \multicolumn{2}{|c|}{2007} & $3.65^{b}$ & $47.46^{b}$ & $6.9^{\mathrm{c}}$ & $26.79^{c}$ & 0.13 & $6.32^{a}$ & $2.27^{\mathrm{a}}$ & $13.17^{\mathrm{a}}$ & $73.34^{a}$ \\
\hline \multicolumn{2}{|c|}{2008} & $4.07^{\mathrm{a}}$ & $47.29^{b}$ & $10.6^{a}$ & $28.60^{b}$ & 0.12 & $6.20^{\mathrm{a}}$ & $2.11^{\mathrm{b}}$ & $11.44^{b}$ & $73.59^{a}$ \\
\hline \multicolumn{2}{|c|}{2009} & $3.73^{b}$ & $49.50^{\mathrm{a}}$ & $8.8^{b}$ & $29.51^{a}$ & 0.11 & $5.84^{\mathrm{b}}$ & $1.92^{\mathrm{c}}$ & $9.87^{\mathrm{c}}$ & $71.62^{b}$ \\
\hline \multicolumn{2}{|c|}{ Average } & 3.82 & 48.08 & 8.8 & 28.3 & 0.12 & 6.12 & 2.10 & 11.49 & 72.85 \\
\hline \multicolumn{2}{|c|}{$\mathrm{R}$} & & $* *$ & & ns & ns & ns & $* *$ & ns & $* *$ \\
\hline \multicolumn{2}{|r|}{$\mathrm{Y}$} & $* *$ & $* *$ & $* *$ & $* *$ & ns & $* *$ & $* *$ & $* *$ & $* *$ \\
\hline \multicolumn{2}{|c|}{ R X Y } & $* *$ & $* *$ & $* *$ & ns & ns & ns & $*$ & $* *$ & $* *$ \\
\hline
\end{tabular}

** Means within columns but not followed by the same letter are significantly different at the $\mathrm{p}<0.01$ level by Duncan's multiple range test. ns: Not significant

Table 5. Evapotranspiration, irrigation, seasonal irrigation water quantities, saving, water use efficiencies and yield of safflower for the treatments

\begin{tabular}{c|c|c|c|c|c|c|c}
\hline Subjects & Application & $\begin{array}{c}\mathbf{E T} \\
(\mathbf{m m})\end{array}$ & $\begin{array}{c}\text { Irrigation } \\
(\mathbf{m m})\end{array}$ & $\begin{array}{c}\text { Number of } \\
\text { irrigation }\end{array}$ & $\begin{array}{c}\text { Irrigation } \\
\text { water saving } \\
(\mathbf{\%})\end{array}$ & $\begin{array}{c}\mathbf{W U E} \\
\mathbf{k g ~ h a}^{-1} \mathbf{m m}^{-\mathbf{1}}\end{array}$ & $\begin{array}{c}\text { IWUE } \\
\mathbf{k g ~ h a}^{-1} \mathbf{m m}^{-\mathbf{1}}\end{array}$ \\
\hline $\mathrm{S}_{1}$ & $\mathrm{VFY}$ & 591 & 428 & 3 & - & $8.8^{\mathrm{c}}$ & 11.92 \\
$\mathrm{~S}_{2}$ & $\mathrm{VFY}_{0}$ & 459 & 266 & 2 & 37.9 & $9.1^{\mathrm{c}}$ & 15.58 \\
$\mathrm{~S}_{3}$ & $\mathrm{VF}_{0} \mathrm{Y}$ & 451 & 272 & 2 & 36.4 & $8.1^{\mathrm{d}}$ & 13.10 \\
$\mathrm{~S}_{4}$ & $\mathrm{~V}_{0} \mathrm{FY}$ & 510 & 317 & 2 & 25.9 & $8.0^{\mathrm{d}}$ & 12.13 \\
$\mathrm{~S}_{5}$ & $\mathrm{VF}_{0} \mathrm{Y}_{0}$ & 322 & 111 & 1 & 74.1 & $10.2^{\mathrm{ab}}$ & 29.28 \\
$\mathrm{~S}_{6}$ & $\mathrm{~V}_{0} \mathrm{FY}_{0}$ & 364 & 155 & 1 & 63.8 & $9.9^{\mathrm{b}}$ & 22.68 \\
$\mathrm{~S}_{7}$ & $\mathrm{~V}_{0} \mathrm{~F}_{0} \mathrm{Y}$ & 335 & 161 & 1 & 62.4 & $10.6^{\mathrm{a}}$ & 21.32 \\
$\mathrm{~S}_{8}$ & $\mathrm{~V}_{60} \mathrm{FY}$ & 553 & 383 & 3 & 10.5 & $8.0^{\mathrm{d}}$ & 11.11 \\
$\mathrm{~S}_{9}$ & $\mathrm{~V}_{40} \mathrm{FY}$ & 536 & 361 & 3 & 15.7 & $7.9^{\mathrm{d}}$ & 11.20 \\
$\mathrm{~S}_{10}$ & $\mathrm{VF}_{60} \mathrm{Y}$ & 554 & 365 & 3 & 14.7 & $7.7^{\mathrm{d}}$ & 11.32 \\
$\mathrm{~S}_{11}$ & $\mathrm{VF}_{40} \mathrm{Y}$ & 499 & 334 & 3 & 22.0 & $7.9^{\mathrm{d}}$ & 11.31 \\
$\mathrm{~S}_{12}$ & $\mathrm{VFY}_{60}$ & 544 & 363 & 3 & 15.2 & $7.8^{\mathrm{d}}$ & 11.23 \\
$\mathrm{~S}_{13}$ & $\mathrm{VFY}_{40}$ & 513 & 331 & 3 & 22.7 & $7.8^{\mathrm{d}}$ & 11.65 \\
$\mathrm{~S}_{14}$ & $\mathrm{~V}_{0} \mathrm{~F}_{0} \mathrm{Y}_{0}$ & 234 & 0 & 0 & 100 & $10.8^{\mathrm{a}}$ & - \\
\hline
\end{tabular}



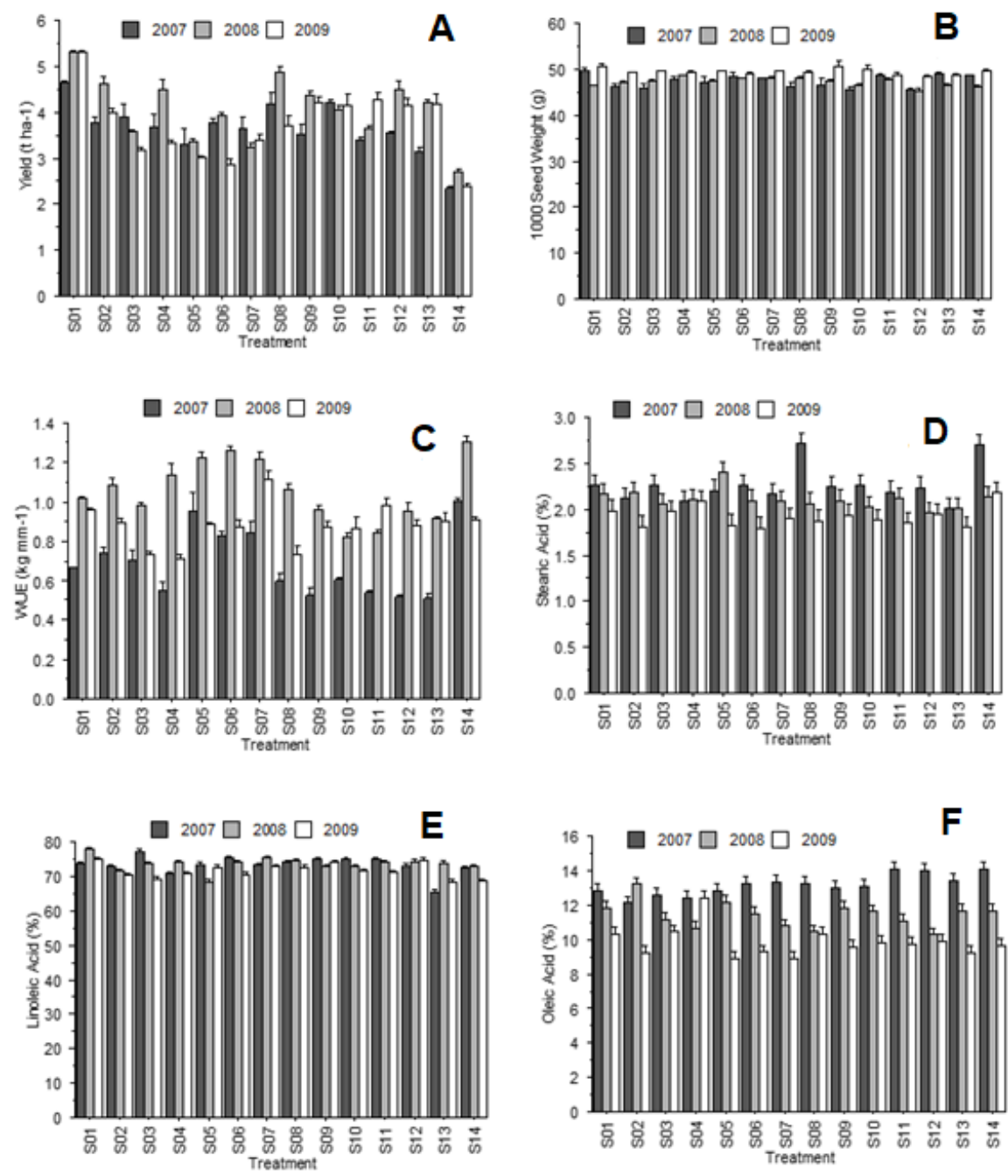

Figure 1. Duncan grouped data in the experiment. A, yield $\left(t h a^{-1}\right) ; B, 1000$ Seed weight $(g) ; C$, WUE, $\mathrm{kg} \mathrm{mm}^{-1} ;$ D, stearic acid (\%); E, Linoleic acid (\%); F, Oleic acid (\%)

While Leonard and French (1968) obtained the highest yield as $3.68 \mathrm{t} \mathrm{ha}^{-1}$ with irrigation until the end of flowering, the lowest yield was obtained as $0.8 \mathrm{t} \mathrm{ha}^{-1}$ from irrigated subject applied until the beginning of flowering. Albel (1976) stated that the flowering period reached the maximum value of plant water consumption and that termination of irrigation during this period caused significant losses in yield. Hang and Evans (1985) indicated that water stress causes shortening in plant height, early flowering, early ripening and decrease in seed yield. Dashora and Sharma (2006) received the highest seed yield from the subject that was irrigated twice during flowering and yield formation periods. Nabipour et al. (2007) obtained the highest yield from the subject of full irrigation, whereas the lowest yield was obtained from the subject without irrigation during the flowering period. Istanbulluoglu et al. (2009) said that the effect of preflowering water deficit on winter safflower cultivation had more effect on the yield. Ghamarnia et al. (2010) mentioned that seed yield depends on the amount of water available in the soil. Sharrifmoghaddasi and Omidi (2010) point out that the effect on yield components of stopping irrigation after the flowering period is weak. Jabbari et al. (2010) reported that water limitation before flowering causes drastic effects. Omidi et al. 
(2012) stated that drought stress before flowering importantly influenced seed yield per plant and the number of buds per plant. The reduction rate of grain yield of safflower changed from about $10 \%$ to $38 \%$, considering the decrease of soil moisture level. Santos et al. (2018) specified that deficit irrigation in phenological stages remarkably impacted plant height, diameter, length, fresh weight, dry weight and number of stems. They pointed out the benefit of irrigation during the vegetation period but stated that irrigation during the flowering period was more effective.

\section{Seed Weight}

The highest 1000 seed weight is achieved in full irrigation, while there is a significant reduction in limited irrigation issues. The 1000 seed weights obtained in the third year of the experiment are higher than in the first two years. While the $S_{5}, S_{8}, S_{9}, S_{11}, S_{13}$ and $S_{14}$ subjects are in the same group statistically, the data of the $S_{4}, S_{6}$ and $S_{7}$ subjects are listed after the statistics of full irrigation. The effect of full watering during the vegetative period led to a higher seed weight of 1000 compared to the flowering and yield formation periods. The graph of the 1000 seed weight in the experiment carried out is given in Figure 1-B.

\section{Irrigation Water Use Efficiency (IWUE)}

The highest IWUE value was obtained from the $\mathrm{S}_{14}$ subjects where no irrigation was applied and from the $S_{7}$ subjects where irrigation was performed only during the yield formation period. Full irrigation did not give the highest IWUE value. The lowest IWUE values were observed in $S_{3}, S_{4}, S_{8}, S_{9}, S_{10}, S_{11}, S_{12}$ and $S_{13}$, in which $40 \%$ and $60 \%$ of deficit water were applied in the vegetative, flowering and yield formation periods. Subject $S_{1}$ and subject $S_{2}$ were statistically in the same group. In the annual assessment, all trial years were in different groups, while in 2008 group A, which received the least rainfall during the irrigation period, in Group B in 2009 and in 2007, in which the highest rainfall occurred in the vegetative period were in the (c) group. The graph of the IWUE in the experiment is given in Figure 1-C.

Low irrigation water applications generally resulted in higher IWUE values. Our results are in agreement with Lovelli et al. (2007), Istanbulluoglu (2009) and Singh et al. (2016). Conversely, Kar et al. (2007) indicated an increase in the water use of the additional irrigation number. As the irrigation number increased, the IWUE value increased. In a two-year study, the IWUE value was $1.23 \mathrm{~kg} \mathrm{ha}^{-1} \mathrm{~mm}^{-1}$ with one irrigation and $2.11 \mathrm{~kg} \mathrm{ha}^{-1} \mathrm{~mm}^{-1}$ with a $71 \%$ increase with two irrigations. The highest IWUE was achieved with the mean value being $2.96 \mathrm{~kg} \mathrm{ha}^{-1} \mathrm{~mm}^{-1}$ with three supplemental irrigations. Abd El-Lattief (2013) obtained the highest IWUE value for irrigation when there was a $50 \%$ reduction in soil moisture levels with 20 plants per square meter.

\section{Oil Rate and Fatty Acid Composition}

The irrigation subjects applied did not have any effect on the oil ratio of the safflower. The results of this study are also confirmed by Albel (1976), Hang and Evans (1985), Hamrouni et al. (2007) and Omidi et al. (2012). Conversely, while Amini et al. (2013) determined an $8.8 \%$ reduction of the mean oil content due to water-deficit stress, Hasanvandi et al. (2014), observed an increase in oil content under irrigation conditions.

When the results of the fatty acid composition were taken into account, no effect of restricted irrigation practices on fatty acids other than stearic and linoleic acid could be 
determined. In the stearic acid composition, where four different groups were formed, the subject $S_{14}$, where irrigation water was never applied, formed group (a). The graphs of the stearic, oleic and linoleic acid composition are given in Figures 1-D, 1-E and 1-F, respectively. Similar findings were found by Cosge et al. (2007). Hamrouni et al. (2007) indicated that excessive water stress led to a decrease in linoleic acid ratios, while moderate stress increased all the fatty acids proportionately. Ashrafi and Razmjo (2010) found that stearic, oleic and linoleic fatty acids in the safflower plant decreased by 5 to $14 \%$ depending on the degree of drought stress.

\section{Irrigation water requirements and evapotranspiration}

Table 5 summarizes the average evapotranspiration, irrigation water requirement, the number of irrigation treatments, conserved proportional irrigation water, WUE, IWUE and the yield values of applied irrigation water issues.

The amount of irrigation water applied to the experimental subjects and plant water consumption values differed due to variable climatic conditions and precipitation. The lowest ET value was naturally occurring at $234 \mathrm{~mm}$ from the subject $\mathrm{S}_{14}$ where no water was given, and the highest ET value was $591 \mathrm{~mm}$ from the subject $S_{1}$ where full irrigation was performed. Although the ET values of $S_{2}$ and $S_{3}$ subjects, which did not irrigate only during the flowering and yield formation periods, showed significant differences during the year, the values were very close to each other on a three-year average. In spite of this proximity in terms of average value of water consumed, the average yield values obtained for 3 years led to the yields per hectare being statistically different in terms of $S_{2}$ and $S_{3}$ yields of 4.14 and 3.56 tons, respectively. In this case, it can be said that the flowering period is more sensitive to water constraints than the yield formation period. In the vegetative period, the average ET value for the $S_{4}$, where irrigation was not performed, was $510 \mathrm{~mm}$ and the average yield was 3.84 tons $\mathrm{ha}^{-1}$. When these three periods are compared with each other, flowering, vegetative and yield formation can be listed in terms of sensitivity to water stress. In this case, when limited irrigation needs to be implemented due to lack of water in the irrigation network, the restriction should be applied in other periods, excluding the flowering period.

For the subjects $S_{5}, S_{6}$, and $S_{7}$ only one irrigation was carried out during the growing period. In terms of ET value, the highest plant water consumption was in the flowering period $\left(S_{6}\right)$ with an average of $364 \mathrm{~mm}$, followed by yield formation $\left(S_{7}\right)$ with $335 \mathrm{~mm}$ and vegetative $\left(S_{5}\right)$ with $322 \mathrm{~mm}$. Although the ET values of the $S_{6}$ and $S_{7}$ periods showed a $42 \mathrm{~mm}$ consumption difference on average, they were in the same group in terms of average yield with 3.56 and $3.52 \mathrm{tha}^{-1}$ yield, respectively. In this case, it can be said that there will not be any difference in the preference of one of the flowering or yield formation periods in irrigation networks where there is only one irrigation opportunity during the year.

The subjects $S_{8}, S_{10}$, and $S_{12}$, where $60 \%$ water is applied for a single period compared to full irrigation, represent subjects where irrigation is applied at $60 \%$ during the vegetation, flowering, and yield formation periods. This means that two of these three periods are fully irrigated and $60 \%$ of water is applied for the remaining period. The mean ET values of $S_{8}$ and $S_{10}$ were 553 and $554 \mathrm{~mm}$, respectively, and the yield values were 4.25 and $4.13 \mathrm{t} \mathrm{ha}^{-1}$, respectively. While the $S_{8}$ and $S_{10}$ issues are in the same group in terms of yield, their irrigation water needs are 383 and $365 \mathrm{~mm}$, respectively. The ET value for $\mathrm{S}_{12}$ was $544 \mathrm{~mm}$, the yield was $4.07 \mathrm{t} \mathrm{ha}^{-1}$ and the irrigation water requirement was $363 \mathrm{~mm}$. 
The subjects $S_{9}, S_{11}$, and $S_{13}$ represent subjects where $40 \%$ of total irrigation is provided during water application periods. These issues indicate that $40 \%$ of the full irrigation is given in the plant root zone and the other two periods are fully irrigated. The measured ET values for these subjects are $536 \mathrm{~mm}, 499 \mathrm{~mm}$ and $513 \mathrm{~mm}$, respectively. The yield values obtained for these subjects, where irrigation water was applied three times, were 4.04, 3.78 and 3.85 tons per hectare, respectively, and each of them was statistically different. The water savings for the subjects were $15.7 \%, 22 \%$, and $22.7 \%$, respectively, whereas all three subjects were in the same group in terms of water application efficiency. The results of the yield-response factor are given in Figure 2.
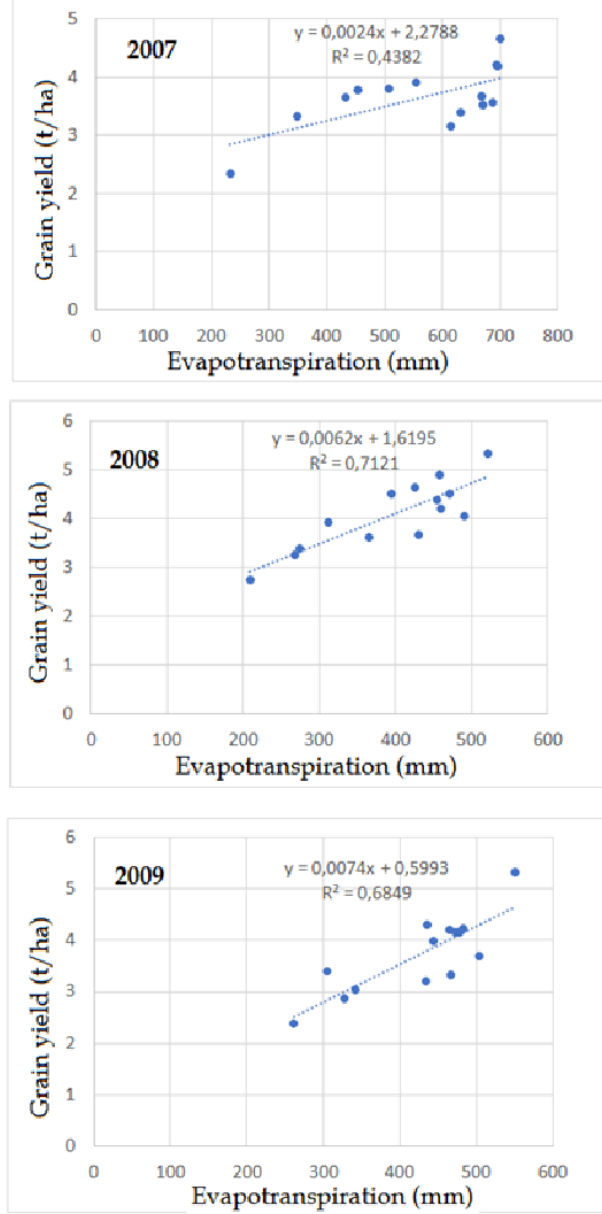

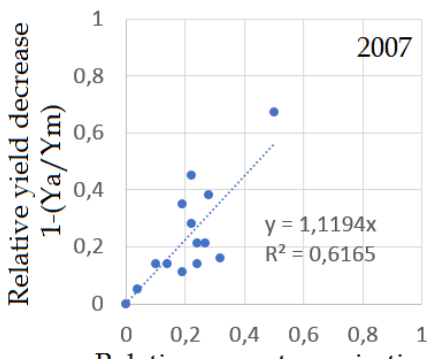

Relative evapotranspiration 1- $(\mathrm{ETa} / \mathrm{ETm})$

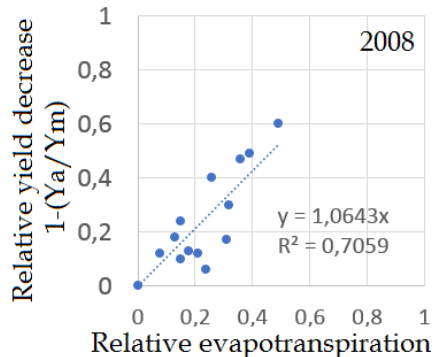

1- $(\mathrm{ETa} / \mathrm{ETm})$

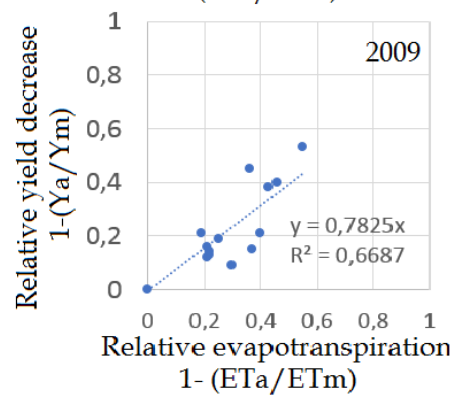

Figure 2. Relationship between grain yield and evapotranspiration (left side), Relationship between relative evapotranspiration deficit $1-\left(E T_{a} / E T_{m}\right)$ and relative yield decrease $1-$ $\left(Y_{a} / Y_{m}\right)($ confidence level $p<0.01)$ (right side)

\section{Water-yield relationships and yield response factor $\left(k_{y}\right)$}

Irrigation water and plant water consumption and yields of the subjects were evaluated mutually and water-yield relationships were obtained during the experiment. Since yields obtained from plant water consumption values vary from year to year, water-yield relationship graphs are given separately for the years in which the experiment is 
conducted. Since the maximum amount of irrigation water applied does not exceed the field capacity, the water yield relation is indicated by a linear equation.

The $\mathrm{k}_{\mathrm{y}}$ values for the experimental years of 2007, 2008 and 2009 were $0.77,0.84$ and 1.15 , respectively $($ mean $=0.92)$. The obtained $\mathrm{k}_{\mathrm{y}}$ values for the whole growth period in this study were very close to the value of 0.80 proposed by Doorenbos and Kassam (1979), 0.93 by Lovelli et al. (2007) and 0.97 by Istanbulluoglu et al. (2009). The yield response factor $\left(\mathrm{k}_{\mathrm{y}}\right)$ for each specific growth period proved to be an important criterion to decide which stage was the most sensitive to water. According to Lovelli et al. (2007), the $\mathrm{k}_{\mathrm{y}}$ value, which is under 1 for safflower, indicates that the decrease in production is very low. It means that there is not much change in yield and that the plant is more resistant to water stress. Pourghasemin and Zahedi (2009) indicated that the effects of the decrease in soil moisture levels on plant growth vary according to the percentage of flowering. The decrease in soil moisture, plant height, leaf area index, plant dry matter, the number of trays per plant, bud seed weight and seed number per harvest index were not reduced at $50 \%$ of flowering. On the other hand, the decrease in soil moisture in the period when flowering is $100 \%$ leads to a decrease in these characteristics.

Phenological periods were evaluated separately by taking into consideration the values obtained during the three years of the study. The mean values obtained for the vegetation, flowering, and yield formation periods were 1.03, 1.18 and 1.00, respectively. In this case, the flowering period takes the first place in terms of its effect on yield, followed by the vegetative and yield formation periods. According to Istanbulluoglu et al. (2009), the safflower plant is most susceptible to water stress during the vegetative period, whereas Omidi et al. (2012) and Santos et al. (2018) stated that it was most susceptible during the flowering period.

\section{Conclusions}

The obtained results showed that for maximum yield in safflower cultivation, irrigation should be done without problems during all developmental stages of the plant. The flowering period is the most sensitive period for safflower productivity. Therefore, there is no compensation for the water deficit during the flowering period. The yield formation period was determined to be the second most sensitive period for soil moisture in terms of irrigation. Irrigation during this period increases the weight of 1000 grains, with especially the hectoliter weight being higher. When the $\mathrm{k}_{\mathrm{y}}$ values obtained are evaluated together with the yield, the effect of water stress that may occur during the yield formation is seen. In this study, the effects of the safflower plant on the fat content and the fatty acid composition were investigated. The results showed that water deficit had no effect on the fat ratio, but it was found that water deficit did affect the stearic and linoleic acid ratios in the fatty acid compositions.

\section{REFERENCES}

[1] Abd El-Lattief, E. A. (2013): Impact of integrated use of bio and mineral nitrogen fertilizers on productivity and profitability of wheat (Triticum aestivum L.) under Upper Egypt conditions. - International Journal of Agronomy and Agricultural Research 3(12): 67-73.

[2] Albel, G. H. (1976): Effects of irrigation regimes, planting dates, nitrogen levels and row spacing on safflower cultivars. - Agronomy Journal 68(3): 448-451.

[3] AOCS. (1993): Official methods and recommended practices of the American Oil 
Chemists' Society. - AOCS Press, Champaign, U.S.A.

[4] Ashrafi, E., Razmjo, K. (2010): Effect of Irrigation Regimes on Oil Content and Composition of Safflower (Carthamus tinctorius L.) Cultivars. - Journal of the American Oil Chemists' Society 87(5): 499-506.

[5] Bacelar, E. L. V. A., Moutinho-Pereira, J. M., Berta, M. C., Gonçalves, C. V. Q., GomesLaranjo, B. J., Ferreira, H. M. F., Correia, C. M. (2013): Water use strategies of plants under drought conditions. - In: Aroca, R. (ed.) Plant Responses to Drought Stress. DOI: 10.1007/978-3-642-32653-0_6. Book ISBN: 978-3-642-32652-3.

[6] Boyac1, H., Karas, E. (2011): Water-yield relationships of safflower plant in Eskişehir conditions. - II. National Soil and Water Resources Congress, Kizılcahamam-Ankara.

[7] Caloiero, T., Simone Veltri, I. D., Caloiero, P., Frustaci, F. (2018): Drought Analysis in Europe and in the Mediterranean Basin Using the Standardized Precipitation Index. Water 10: 1043. DOI:10.3390/w10081043.

[8] Choudhury, B. U., Singh, A. K. (2016): Estimation of crop coefficient of irrigated transplanted puddled rice by field-scale water balance in the semi-arid Indo-Gangetic Plains, India. - Agricultural Water Management 176: 142-150. https://doi.org/10.1016/j.agwat.2016.05.027.

[9] Cook, B. I., Smerdon, J. E., Seager, R., Coats, S. (2014): Global warming and 21-st century drying. - Climate Dynamics 43: 2607-2627. DOI 10.1007/s00382-014-2075-y.

[10] Cosge, B., Gürbüz, B., Kıralan, M. (2007): Oil Content and Fatty Acid Composition of Some Safflower (Carthamus tinctorus L.) Varieties Sown In Spring and Winter. International Journal Of Natural And Engineering Sciences 1(3): 11-16.

[11] Dashora, P., Sharma, R. P. (2006): Effect of sowing date, irrigation and sulphur nutrition on yield attributes, yield and oil content of safflower. - Crop Research 31(1): 56-57.

[12] Diogo, V. P. N. N. (2018): Agricultural land systems: explaining and simulating agricultural land-use patterns. - Ph.D. Thesis, Vrije Universiteit, p. 340, Amsterdam.

[13] Doorenbos, J., Kassam, A. H. (1979): Yield response to water. - Irrigation and Drainage, pp 33. FAO, United Nations, Rome.

[14] Ghamarnia, H., Khosravy, H., Sepehri, S. (2010): Yield and water use efficiency of (Nigella sativa L.) under different irrigation treatments in a semi arid region in the West of Iran. - Journal of Medicinal Plants Research 4(16): 1612-1616.

[15] Gouveia, C. M., Trigo, R. M., Beguería, S., Vicente-Serrano, S. M. (2017): Drought impacts on vegetation activity in the Mediterranean region: An assessment using remote sensing data and multi-scale drought indicators. - Global and Planetary Change 151: 1527. https://doi.org/10.1016/j.gloplacha.2016.06.011.

[16] Grecksch, K. (2019): Scenarios for resilient drought and water scarcity management in England and Wales. - International Journal of River Basin Management 17(2): 219-227.

[17] Hamrouni, I., Salah, H., Marzouli, B. (2007): Effects of Water- Dificit on Lipids of Safflower Aierial Parts. - Phytochemistry 58(2): 277-280. https://doi.org/10.1016/S00319422(01)00210-2.

[18] Hang, A. N., Evans, D. W. (1985): Deficit Sprinkler Irrigation of Sunflower and Safflower. - Agronomy Journal 77(4): 588-592.

[19] Hertig, E., Tramblay, Y. (2017): Regional downscaling of Mediterranean droughts under past and future climatic conditions. - Global and Planetary Change 151: 36-48. https://doi.org/10.1016/j.gloplacha.2016.10.015.

[20] Howell, T. A., Tolk, J. A., Schneider, A. D., Evett, S. R. (1998): Evapotranspiration, Yield, and Water Use Efficiency of Corn Hybrids Differing in Maturity. - Agronomy journal 90(1). DOI:10.2134/agronj1998.00021962009000010002x.

[21] Istanbulluoglu, A. (2009): Effects of irrigation regimes on yield and water productivity of safflower (Carthamus tinctorius L.) under Mediterranean climate conditions. - Agric. Water Management 96: 1792-1798.

[22] Istanbulluoglu, A., Gocmen, E., Gezer, E., Pasa, C., Konukcu, F. (2009): Effects of water stress at different development stages on yield and water productivity of winter and summer 
safflower (Carthamus tinctorius L.). - Agricaltural Water Management 96: 1429-1434.

[23] Jabbari, M., Ebadi, A., Tobeh, A., Mostafaii, H. (2010): Effects of supplemental irrigation on yield and yield components of spring safflower genotypes. - Recent Res. Sci. Technol. 2: 23-28.

[24] Kar, G., Kumar, A., Martha, M. (2007): Water use efficiency and crop coefficients of dry season oilseed crops. - Agricultural Water Management 87(1): 73-82.

DOI: 10.1016/j.agwat.2006.06.002.

[25] Leonard, J., French, O. F. (1968): Growth yield and yield components of safflower as affected by irrigation regimes. - Agron. J. 61: 111-113. DOI:10.2134/agronj1969.00021962006100010037x.

[26] Lionello, P., Ozsoy, E., Planton, S., Zanchetta, G. (2017): Climate Variability and Change in the Mediterranean Region. - Global, and Planetary Change 151: 1-152.

[27] Lovelli, S., Perniola, M., Ferrara, A., Tommaso, T. D. (2007): Yield response factor to water (ky) and water use efficiency of Carthamus tinctorius L. and Solanum melongena L. - Agricultural Water Management 92: 73-80.

[28] Nabipour, M., Meskerbashee, M., Yousefpour, H. (2007): The effect of water deficit on yield and yield components of safflower (Carthamus tinctorius L.). - Pak J Biol Sci 10(3): 421-6.

[29] Omidi, A. H., Khazaei, H., Monneveux, P., Stoddard, F. (2012): Effect of cultivar and water regime on yield and yield components in safflower (Carthamus tinctorius L.). - Turkish Journal of Field Crops 17(1): 10-15.

[30] Öztürk, Ö., Ada, R., Akınerdem, F. (2009): Determination of yield and yield components of some safflower cultivars in irrigated and dry conditions. - Selçuk University Journal of Agricultural and Food Sciences 23(50): 16-27. ISSN:1309-0550.

[31] Pan, T., Chen, J., Liu, Y. (2018): Spatial and Temporal Pattern of Drought Hazard under Different RCP Scenarios for China in the $21^{\text {st }}$ century. - https://doi.org/10.5194/nhess2018-242.

[32] Pankova, Ye. I., Konyushkova, M. V. (2014): Effect of Global Warming on Soil Salinity of the Arid Regions. - Russian Agricultural Sciences 39(5-6): 464-467. ISSN 10683674.

[33] Pourghasemin, N., Zahedi, M. (2009): Effects of Planting Pattern and Level of Soil Moisture on Yield and Yield Components of Two Safflower Cultivars in Isfahan. http://www.doaj.org.

[34] Rahiz, M., New, M. K. (2012): 21st Century Drought Scenarios for the UK. - Water Resources Management 27(4): 1039-1061. DOI: 10.1007/s11269-012-0183-1.

[35] Santos, R. F., Bassegio, D., Silva, M. A., Klar, A. E., Silva, A. A. F., Silva, T. R. B. (2018): Irrigated safflower at different phenological stages of Brazilian southeast dry season. Irriga 23(3): 493.

[36] SAS Institute. (1998): Statistical Analysis System Institute: StatView Reference Manual. SAS Institute, Cary, NC.

[37] Shammout, M. W., Qtaishat, T., Rawabdeh, H., Shatanawi, M. (2018): Improving Water Use Efficiency under Deficit Irrigation in the Jordan Valley. - Sustainability 10: 4317. DOI:10.3390/su10114317.

[38] Sharrifmoghaddasi, M., Omidi, A. H. (2010): Study of interrupting irrigation effects at different growth stages on grain and oil yields of new safflower varieties. - Advances in Environmental Biology 4(3): 387-391. ISSN 1995-0756.

[39] Shkolnika, I. M., Pigol'tsinaa, G. B., Efimov, S. V. (2019): Agriculture in the Arid Regions of Eurasia and Global Warming: RCM Ensemble Projections for the Middle of the 21st Century. - Russian Meteorology and Hydrology 44(8): 540-547. ISSN 1068-3739.

[40] Singh, S., Angadi, S. V., Grover, K., Begna, S., Auld, D. (2016): Drought response and yield formation of spring safflower under different water regimes in the semiarid Southern High Plains. - Agricultural Water Management 163: 354-362.

DOI: 10.1016/j.agwat.2015.10.010.

[41] Stewart, J. I., Cuenca, R. H., Pruit, W. O., Hagan, R. M., Tosso, J. (1977): Determination 
and utilization of water production functions for principal California crops. - W-67 California Contributory Project, University of California, California, USA.

[42] SWRI. (2011): Climatological data of the Soil and Water Research Institute of Eskisehir (1957-2011). - Unplished report, $12 \mathrm{p}$.

[43] TUIK. (2018): Turkish Statistical Institute. Agricultural Statistics. http://tuik.gov.tr/UstMenu.do?metod=temelist [Accessed 28.09.2019].

[44] Tüzüner, A. (1990): Soil and Water Analysis Laboratory Handbook. - Ministry of Agriculture, General Directorate of Rural Service, Ankara.

[45] Ward, F. A., Pulido-Velazquez, M. (2008): Water conservation in irrigation can increase water use. - Proceedings of the National Academy of Sciences of the United States of America 105(47): 18215-18220. DOI:10.1073/pnas.0805554105.

[46] Yurtsever, N. (1984): Experimental Methods in Statistics. - Ministry of Agriculture and Rural Affairs, Ankara, Turkey: 625-632. 